\title{
Predictors of Wellbeing Among Older Adults Participants of a U3A
}

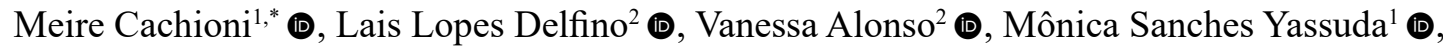 \\ Samila Sathler Tavares Batistoni ${ }^{1}$ (D), Ruth Caldeira Melo ${ }^{1}$ (D), \\ \& Marisa Accioly Domingues da Costa Rodrigues ${ }^{1}$ (D) \\ ${ }^{1}$ Universidade de São Paulo, São Paulo, SP, Brasil \\ ${ }^{2}$ Universidade Estadual de Campinas, Campinas, SP, Brasil
}

\begin{abstract}
This study aimed to identify predictive factors for subjective and psychological well-being in a sample of 265 older adults enrolled in the University of the Third Age (U3A). The scales used were: General Satisfaction with Life Scale and referenced to the domains, Positive and Negative Affect Scale and Personal Development Scale. Multivariate logistic analysis indicated that being 70 or older and male was associated with the subjective well-being and having higher education level was associated with psychological well-being. It was concluded that sociodemographic characteristics of the interviewed elders enrolled in U3A can be important attributes that influence well-being.
\end{abstract}

KEYWORDS: aging, well-being, aged, U3A

\section{Fatores Preditores de Bem-estar em Idosos Participantes de uma UATI}

\begin{abstract}
RESUMO - Objetivou-se identificar os fatores de predição para as variáveis de bem-estar subjetivo e psicológico em uma amostra de 265 alunos idosos participantes em uma Universidade Aberta à Terceira Idade (UATI). As escalas utilizadas foram: Escalas de Satisfação Geral com a Vida e referenciada aos domínios, Escala de Estado de Ânimo e Escala de Desenvolvimento Pessoal. Resultados significativos das análises multivariadas indicaram que ter 70 anos ou mais e ser do sexo masculino associaram-se com bem-estar subjetivo, enquanto possuir nível elevado de escolaridade associou-se com maiores níveis de bem-estar psicológico. Conclui-se que as características sociodemográficas dos idosos entrevistados podem ser importantes atributos que influenciam o bem-estar de idosos frequentadores de UATIs.
\end{abstract}

PALAVRAS-CHAVE: envelhecimento, bem-estar, idosos, UATI

\section{INTRODUCTION}

The stereotype that the elderly are unhappy with the aging process, that they are alone, isolated, abandoned and sick, is not true. Thanks to advances in the psychology of aging, new knowledge based on the lifespan perspective (development throughout life) reveals the dynamics of well-being and the factors that influence its maintenance or decline in old age (Mroczek et al., 2020). In the 1990s, a new paradigm emerged: the well-being paradox (Lawton, 1991). Some research has shown that, despite the challenges and losses associated with age, subjective well-being (SWB) and the sense of maturity or psychological well-being (PWB) do not seem to decline, and gains in these indicators may

*E-mail: meirec@usp.br

n Submetido: 15/01/2019; Revisado: 26/06/2020; Aceito: 04/08/2020. 
occur (Chopik et al., 2019; Karppinen et al., 2017). Thus, the study of the life course makes it possible to understand the dynamics of SWB and PWB and the dimension of the functioning of the personality of the mature adult and the elderly.

\section{Subjective Well-Being}

In literature, SWB is defined by three distinct components: satisfaction with life, positive and negative affects. Studies in the area assess how and why people experience their lives in a positive or negative way (Carmel et al., 2017; Carstensen \& DeLiema, 2018). SWB refers to people's evaluative responses about their lives, both cognitive and emotional in nature (Diener \& Ryan, 2009).

In the cognitive domain, individuals can make judgments according to their standards and beliefs about their life in general (satisfaction with life) and about specific domains, such as health, memory, family relationships or social contacts (Kendig et al., 2016). It is a cognitive assessment of life itself, which, however, can be indirectly influenced by emotion. On the emotional level, people react with positive and negative affects to the activities in which they are involved and to life events. Happiness is a judgment that people make comparing these two components (affective balance), and, for SWB, the preponderance of pleasant emotions over unpleasant ones is important (Diener \& Ryan, 2009).

Studies on SWB focus on evaluating its indicators against different variables, mostly sociodemographic, such as age, gender, educational and social level, income, health condition, among others (Kendig et al, 2016; Steptoe et al., 2015). Those studies have contributed to the understanding of basic psychological processes and relationships with objective conditions of life, in addition to promoting initiatives applied to improving the quality of life.

Data from a study conducted in more than 160 countries where SWB measures were compared between different ages revealed that in richer countries welfare was higher among younger older age groups if compared to those in middle age, a pattern that was also observed in relation to life satisfaction. On the other hand, in sub-Saharan Africa, few differences in well-being have been found between different ages, and in Latin America and Eastern Europe, well-being has declined progressively with age (Steptoe et al., 2015).

A longitudinal study in England showed that satisfaction with life increases in older cohorts and increases at a faster pace when marital status and health are controlled. Such data are probably due to the adaptive nature of SWB measures, and show that, even in the face of health declines due to aging, the elderly become more satisfied and happier with the situation in which they live than when they were younger (Jivraj et al., 2014).
Research data explored the relationship between gender and age differences when investigating SWB measures. Batz-Barbarich et al. (2018) conducted a meta-analysis that examined gender differences in life satisfaction and the influence of gender inequality on the size of this difference. Among the 281 samples included, which comprise more than one million individuals, the study showed that after accounting for publication bias, men and women differed significantly in their levels of life satisfaction, so that men reported higher levels satisfaction with life than women.

\section{Psychological Well-Being}

The concept of PWB emerges from criticisms to the fragility of the formulations that supported SWB and to psychological studies that emphasized unhappiness and suffering and neglected the causes and consequences of positive functioning. There are many important aspects for positive psychological functioning that would be absent from studies on SWB. Carol D. Ryff warned about the limitations of literature on psychological adjustment of adults and the elderly; there was an absence of theoretical structures that could encompass a greater number of dimensions of wellbeing and there was certain implicit negativity in relation to the aging process and old age, as little attention was paid to the resources of old age and the possibilities of growth and development in this phase. Another point was lack of understanding that the conceptions of well-being are human constructions open to diverse and competitive definitions, cultural variation and historical changes (Ryff, 1989). Thus, Ryff and Keyes (1995) proposed a multidimensional model of psychological well-being that encompassed six dimensions: autonomy, mastery of the environment, personal growth, purpose of life, positive relationships with others and self-acceptance.

Being well psychologically is more than being free from discomfort or other psychological dysfunctions; it means having a positive outlook on oneself and on life, feelings of dominance and autonomy, quality relationships with others, a sense of purpose and meaning in life. The concept of PWB is associated with emotional and social adjustment insofar as it encompasses the fulfillment of evolutionary tasks and social expectations, considering physical, cognitive and affective attributes, age and gender. It is the search for an ideal of excellence, personal growth or self-realization; it is the constant search for improvement to maintain growth and development. The awareness of this search and the constant shift of goals in relation to higher goals favor adjustment and individual maturity (Ryff, 2018).

Springer (et al., 2011), through a longitudinal study, with a national probabilistic sample of American adults aged 25-74 years, intended to investigate the extent to which the six dimensions of the Ryff PWB Scale (autonomy, 
self-acceptance, positive relationships with others, mastery over the environment, purpose in life and personal growth) have different profiles between age groups and the degree to which methodological variations can affect different ages. The main results highlighted that: a) autonomy declined for each age group; b) personal growth decreased with age at all stages of life, with the exception of the middle age group that remained stable; c) positive relationships with others increased for most groups and remained stable in the oldest group in the study; d) purpose in life decreased for the two younger groups and decreased consistently in the older age groups; e) self-acceptance remained stable among the younger and older groups, while increasing slightly for the middle-aged cohort. The authors concluded that almost all changes related to age revealed by the analysis of this study are very small, despite the statistical significance presented in a large survey.

More recent data, referring to a population sample study conducted in Lithuania, showed that PWB deteriorated in all age groups studied over a 10-year period (Sapranaviciute-Zabazlajeva et al., 2018). Most studies have shown a "U" relationship between PWB and age (i.e., higher PWB among younger and older people and worse PWB among middle-aged people), especially in rich English-speaking countries (Karppinen et al., 2017; Steptoe et al., 2015).

Education is also a variable related to PWB. According to Jongbloed (2018), psychological well-being is influenced by educational levels. In an excess sample of 50,000 individuals in 27 European countries, the data revealed that psychological well-being was influenced by both vocational and higher education, although vocational education had a more significant effect. For the author, education mainly affects well-being indirectly through income, job possibilities and job security. Education can impact feelings of happiness as it favors the creation of social opportunities, which directly contribute to the expansion of human capacities and quality of life.
Higher income and more prestigious occupations are linked to greater well-being, and unemployment has a clear negative relationship with PWB (Gildner et al. Al., 2019). Another element strongly associated with PWB is social relationships, both close personal relationships and social capital, defined by social network, involvement and trust (Aknin et al., 2013).

Studies conducted by Ryff $(1989,1995,2018)$ discuss gender differences in relation to PWB. Gender appears as an important role in the expression of generativity and its consequences on well-being. It was found that women feel more obligations to assist other people and institutions than men. Middle-aged women, with a higher educational level, have an increased self-image and feel more able to guide, advise and teach other people.

It is considered that the current results, in the context of old age, offer little support for the proposed multidimensionality of eudaimonic well-being, a concept that refers to the optimal human functioning and the effort to achieve significant life goals, as measured by the PWB Scale Ryff's. It is known that the relationship between SWB and PWB has not yet been investigated in a population exclusively composed of elderly (60 years old or more) Brazilians attending UATIs, non-formal educational programs for the elderly that aim to offer learning and relationship activities (Aparicio, 2014; Formosa, 2014) contributing to active aging (Gunder, 2014). Participation in educational activities can be positive for both the physical and psychological well-being of the elderly, according to theories of active aging (Narushima et al., 2018). The studies carried out so far have not included all the components of SWB and PWB - global satisfaction with life, satisfaction related to specific domains of experience, positive and negative affects and psychological adjustment. Thus, this study aims to identify the sociodemographic factors that predict the variables of well-being in elderly UATI users and to identify multivariate relationships between the study variables.

\section{METHOD}

\section{Participants}

The study included 265 students enrolled at the Open University of the Third Age of the School of Arts, Sciences and Humanities of the University of São Paulo (EACH-USP $60+$ ). It is a permanent education program for updating and acquiring new knowledge aimed at promoting the health and well-being of its elderly participants. Through workshops, lectures and undergraduate courses offered every six months, the elderly break paradigms and stereotypes related to old age and the aging process, by demonstrating that it is possible to learn at any stage of the life cycle. The program promotes teaching, research and extension activities, with effective insertion in the university community. EACH-USP $60+$ is aligned with the Unit's pedagogical political project, which reveals great concern with the social demands of the community as well as values university extension.

The elderly who knew how to read and write were included and the elderly with cognitive deficit suggestive of dementia and/or those with severe hearing or vision deficits, which made communication and comprehension of the assessment extremely difficult, were excluded. 


\section{Instruments}

For the present study, sociodemographic variables and psychosocial measures of interest related to SWB and PWB were selected.

Among the sociodemographic variables, age, sex and education were chosen because they are important indicators of SWB present in literature. The time of participation in EACH-USP $60+$ was investigated in order to assess the impact of the program on SWB and PWB. Another variable investigated refers to participation in other UATIs or social centers for the elderly, which aimed to assess the impact of other types of educational/social interaction programs on SWB and PWB.

The SWB measures used were: (a) General Life Satisfaction Scale - single item scale that asks for assessment of this condition on a scale from 1 to 10 presented graphically ( $1=$ the worst life and $10=$ the best life) (Santos , 2003); (b) Life Satisfaction Scale referenced to three domains health and physical capacity, mental capacity and social involvement (Santos, 2003). The assessment is made on a five-point scale ranging from very little to very satisfied; (c) Positive and Negative Mood State Scale - on a scale ranging from 1 (little) to 5 (extremely), the subject is asked to evaluate his positive mood, composed of six expressions (happy, cheerful, excited, well, satisfied, contented) and his negative mood, indicated by eight expressions (irritated, unmotivated, anguished, depressed, upset, nervous, sad, discouraged) (Siqueira et al., 1999).

In order to investigate PWB, the Personal Development Scale (PDS) - version with 25 items was applied. PDS originally contained 18 items corresponding to six domains of PWB (positive relationships with others, personal growth, personal acceptance, autonomy, purpose of life and domain of the environment), as described by Ryff
(1989) and 12 items corresponding to three domains generativity (create, maintain and offer). Each item is evaluated by a five-point scale $(1=$ never; 2 = rarely; 3 = occasionally; 4 = frequently; $5=$ very frequently). Methodological study on the instrument revealed a factorial structure containing five factors composed of 25 items, explanatory of $54.04 \%$ of total variability. These factors were called: self-realization, personal growth and psychological adjustment (Factor 1); productivity (Factor 2 ); care (Factor 3); concern for the next generations (Factor 4) and commitment to the other (Factor 5) (Queroz, 2008).

\section{Data analysis}

In order to describe the profile of the sample, according to the various variables under study, frequency tables of categorical variables and descriptive statistics were made, such as measures of position and dispersion of continuous variables.

In order to study the relationship between sociodemographic and psychological variables with the criterion variables (SWB and PWB scores), logistic regression analysis, univariate and multivariate models were used, with stepwise forward criteria for the selection of variables, that is, the simplest model for the most complex. The variables that obtained $p<0.10$ in the simple regression analysis were included in the final multiple models (Hair et al., 2005). When this last analysis was carried out, the continuous variables used in the logistic regression were transformed into categorical from their quartiles.

All data were entered in the Epidata Program version 3.1. For statistical analysis, the computer programs SPSS version 17.0 and Statistica version 7.0 were used. The level of significance adopted for the statistical tests was $5 \%$, that is, $\mathrm{p}$ value $<0.05$.

\section{RESULTS}

Regarding sociodemographic variables, the sample $(\mathrm{n}=$ 265 ) was mostly composed of people aged 60 to 64 years $(40.75 \% ; \mathrm{M}=67 ; \mathrm{SD}=5.48)$, with a predominance of female gender (68.68\%). Most had completed high school (35.47\%; $\mathrm{M}=10.0 ; \mathrm{SD}=4.69)$. Most of the sample $(\mathrm{n}=184)$ was composed of veteran students from the EACH-USP 60+ program, and 81 were new students, as they had enrolled in the activities, as detailed in Table 1.

The univariate analyzes showed significant associations between having high levels of General Satisfaction with Life, being over 70 years old $(\mathrm{OR}=2.30 ; \mathrm{p}=0.005)$, scoring high on Factor 1 of the Personal Development Scale (selfrealization, personal growth and psychological adjustment) $(\mathrm{OR}=3.63 ; \mathrm{p}=0.001)$ and in the total Personal Development Scale $(\mathrm{OR}=3.47 ; \mathrm{p}<0.001)($ Table 2$)$.
The multivariate analysis confirmed the same data evidenced in the univariate analyzes, identifying that elderly people over 70 years old $(\mathrm{OR}=2.27 ; \mathrm{p}=0.007)$ and who scored high on Factor 1 of the Personal Development Scale $(\mathrm{OR}=2.45 ; \mathrm{p}=0.001)$ were twice as likely to have high General Satisfaction with Life rates when compared to elderly people aged 60 to 64 who scored low on Factor 1 of the Personal Development Scale.

Univariate analyzes showed that scoring high on the Satisfaction Scale Referenced to Domains indicated an association with a high score on Factor 1 (self-realization, personal growth and psychological adjustment $)(\mathrm{OR}=2.75$; $\mathrm{p}=0.005)$, Factor 2 (Productivity) $(\mathrm{OR}=2.25 ; \mathrm{p}=0.016)$, Factor 3 (Care) $(\mathrm{OR}=3.21 ; \mathrm{p}<0.001)$ and in the total score of the Personal Development Scale $(\mathrm{OR}=2.25 ; \mathrm{p}<0.001)$. 
The results of the multivariate analysis indicated significant data for the set: high scores on Factor $1(\mathrm{OR}=2.54 ; \mathrm{p}=$ $0.004)$ and on the total Personal Development Scale (OR $=$ 2.32; $\mathrm{p}=0.010$ ), as shown in Table 3.

The high score on the Mood State Scale was associated with being male $(\mathrm{OR}=1.76 ; \mathrm{p}=0.035)$, being 70 years old or older $(\mathrm{OR}=2.30 ; \mathrm{p}=0.005)$, scoring high in the total score and in Factors 1 (self-realization, personal growth and psychological adjustment $)(\mathrm{OR}=2.48 ; \mathrm{p}=0.004)$ and 3 (Care) $(\mathrm{OR}=1.98 ; \mathrm{p}=0.021)$ of the Personal Development Scale $(\mathrm{OR}=2.66 ; \mathrm{p}=0.002)$. In the multivariate analysis, the joint association of the following variables was identified: being 70 years old or older $(\mathrm{OR}=2.57$; $\mathrm{p}=$ 0.002), scoring high on the Personal Development Scale $(\mathrm{OR}=2.08 ; \mathrm{p}=0.006)$ and being male $(\mathrm{OR}=2.20 ; \mathrm{p}=$ 0.008) (Table 4).

As shown in Table 5, the results of the univariate logistic regression analysis for high scores on the total Personal Development Scale indicated significant associations with the variables: high level of education $(\mathrm{OR}=2.21 ; \mathrm{p}=0.040)$, high sense of General Life Satisfaction $(\mathrm{OR}=3.06$; $\mathrm{p}<$
0.001), high level of satisfaction with the health domains $(\mathrm{OR}=1.97 ; \mathrm{p}=0.032)$, physical capacity $(\mathrm{OR}=3.03 ; \mathrm{p}=$ $0.001)$, mental capacity $(\mathrm{OR}=5.29 ; \mathrm{p}=0.020)$ and social involvement $(\mathrm{OR}=3.19 ; \mathrm{p}=0.020)$ and with the total score of the Domain Referenced Satisfaction Scale $(\mathrm{OR}=3.60$; $\mathrm{p}<0.001$ ). Scoring high on the Mood State Scale (OR $=$ 4.07; $\mathrm{p}<0.001)$ was associated with having a high score on the Personal Development Scale (OR $=2.50 ; \mathrm{p}=0.003)$.

Among the variables that showed an association with high scores on the Personal Development Scale, the social involvement domain and the total score of the Domain Referenced Satisfaction Scale stood out. Elderly people who scored high on one of these two scores were at least six times more likely to score high on the Personal Development Scale when compared to those who scored low on these two variables. The results of the multivariate logistic regression analysis revealed the joint association of the variables education $(\mathrm{OR}=2.61 ; \mathrm{p}=0.023)$, social involvement $(\mathrm{OR}=2.97 ; \mathrm{p}=0.002)$ and high scores on the Domain Referenced Satisfaction Scale $(\mathrm{OR}=2.56$; $\mathrm{p}=0.002)$.

\section{DISCUSSION}

Regarding the profile of the participants, there was a higher prevalence of women (68.68\%), data consistent with that of another study involving UATIs (Camargo et al., 2018). Most of the participants in this study had completed high school, a result congruent with that found in another survey (Adamo et al., 2017).

The results of univariate and multivariate logistical analyses confirmed the association between the SWB and PWB constructs. Associations between sociodemographic data and well-being measures were also obtained through the respective analysis: being 70 years old or older was associated with a high score in the total General Satisfaction with Life and Mood State Scales; being male was associated with high scores on the Mood State Scale; having a high level of education was associated with a high score in the total of the Personal Development Scale.

The first study identified in international literature on the relationship between age and life satisfaction by Campbell $e t$ al. (1976) observed data similar to the research carried out at EACH-USP $60+$. The authors identified that older people, when compared to younger groups, were more satisfied and happier with life. Another study did not find a correlation between age and life satisfaction in elderly UATI participants (Zielińska-Więczkowska, 2017).

For Suh and Choi (2018), the elderly have a lower level of aspiration than the younger ones because they are prepared, that is, they were taught not to have high expectations in life. Older people adjust their goals to their resources and skills and thus have lower expectations of achievement and pleasure than younger people; consequently, their assessments of life are more positive. This conclusion exemplifies the role of the self in regulating individual functioning, which refers to the body's ability to produce discrepancies in relation to an expected standard and to create a reactive system that allows the reduction of these discrepancies, resulting in a positive impact on well-being. (Bandura, 2006).

Some authors state that SWB does not decline with age (Karrpinen et al., 2017; Steptoe et al., 2015; Charles \& Carstensen, 2010), a fact verified in the present study. In the researches of the referred theorists, all the findings pointed to a greater satisfaction with life among the elderly and reported that old age is related to the increase in the ability to regulate emotions and to express more positive affects and low levels of negative affects.

These results are also consistent with the lifespan perspective in Psychology (Mroczek et al., 2020). The authors speak of the increase in wisdom and emotional intelligence with advancing age and the decrease in negative affective states as a result of increasing wisdom. The findings are congruent with the Theory of Socioemotional Selectivity, according to which older people have a greater capacity to self-regulate emotions and to see situations in a more positive way (Barber et al., 2016).

For the elderly, the fact of overcoming difficulties and obstacles, as strong and traumatic as they may be, contributes to an adaptation to this phase of life, which is known as resilience (Fontes \&Neri, 2015). According to these authors, 
Table 1

Sample Characterization

\begin{tabular}{|c|c|c|}
\hline Variables & $n$ & $\%$ \\
\hline \multicolumn{3}{|l|}{ Gender } \\
\hline Male & 83 & 31.32 \\
\hline Female & 182 & 68.68 \\
\hline \multicolumn{3}{|l|}{ Age groups } \\
\hline $60-64$ & 108 & 40.75 \\
\hline $65-69$ & 69 & 26.04 \\
\hline 70 or more & 88 & 33.21 \\
\hline Mean $(S D)$ & 67.05 & 5.48 \\
\hline Median & \multicolumn{2}{|c|}{66} \\
\hline Minimum - Maximum & \multicolumn{2}{|c|}{$60.00-86.00$} \\
\hline \multicolumn{3}{|l|}{ Marital status } \\
\hline Single & 35 & 13.21 \\
\hline Married / Civil partnership & 130 & 49.06 \\
\hline Divorced, separated, disconnected & 30 & 11.32 \\
\hline Widowers & 70 & 26.42 \\
\hline \multicolumn{3}{|l|}{ Education (in years) } \\
\hline Up to 4 years & 42 & 15.85 \\
\hline From 5 to 8 years & 73 & 27.55 \\
\hline From 9 to 11 years & 56 & 21.13 \\
\hline 12 years and more & 94 & 35.47 \\
\hline Mean $(S D)$ & 10.07 & 4.69 \\
\hline Median & \multicolumn{2}{|c|}{10} \\
\hline Minimum - Maximum & \multicolumn{2}{|c|}{$0.00-27.00$} \\
\hline \multicolumn{3}{|l|}{ Family income } \\
\hline Up to $2.0 \mathrm{MW}$ & 67 & 25.28 \\
\hline From 2.1 to $3.0 \mathrm{MW}$ & 54 & 20.38 \\
\hline From 3.1 to $4.0 \mathrm{MW}$ & 51 & 19.25 \\
\hline From 4.1 to $5.0 \mathrm{MW}$ & 29 & 10.94 \\
\hline More than $5.1 \mathrm{MW}$ & 64 & 24.15 \\
\hline \multicolumn{3}{|l|}{ Are you participating in a UATI? } \\
\hline No, they were new students & 81 & 30.57 \\
\hline Yes, 1 semester ago & 54 & 20.38 \\
\hline Yes, 1 year ago & 42 & 15.85 \\
\hline Yes, for more than 1 year & 88 & 33.21 \\
\hline \multicolumn{3}{|c|}{ Do you attend another UATI or Community Center? } \\
\hline No & 166 & 62.64 \\
\hline Yes, 1 semester ago & 16 & 6.04 \\
\hline Yes, 1 year ago & 19 & 7.17 \\
\hline Yes, for more than 1 year & 64 & 24.15 \\
\hline
\end{tabular}


Results of the Univariate and Multivariate Logistic Regression Analysis for High General Life Satisfaction Scale

\begin{tabular}{|c|c|c|c|c|c|c|}
\hline \multirow[b]{2}{*}{ Predictive Factors } & \multicolumn{3}{|c|}{ Univariate Analysis } & \multicolumn{3}{|c|}{ Multivariate Analysis } \\
\hline & Odds Ratio & CI 95\% & O.R. & Odds Ratio & $95 \%$ & O.R. \\
\hline \multicolumn{7}{|l|}{ Gender (ref. Male) } \\
\hline Female & 1.30 & 0.77 & 2.20 & & & \\
\hline \multicolumn{7}{|l|}{ Age } \\
\hline $65-69$ & 1.66 & 0.89 & 3.08 & 1.53 & 0.81 & 2.9 \\
\hline 70 or more & $2.30 * *$ & 1.29 & 4.10 & $2.27 * *$ & 1.25 & 4.11 \\
\hline \multicolumn{7}{|l|}{ Education (ref. Up to 4 years) } \\
\hline From 5 to 8 years & 0.68 & 0.32 & 1.46 & & & \\
\hline From 9 to 11 years & 0.62 & 0.28 & 1.39 & & & \\
\hline 12 years or more & 0.54 & 0.26 & 1.12 & & & \\
\hline \multicolumn{7}{|l|}{ Type of Participant (ref. New student) } \\
\hline Senior at EACH-USP $60+$ & 0.75 & 0.39 & 1.44 & & & \\
\hline New student and student from another UATI & 0.66 & 0.24 & 1.79 & & & \\
\hline Senior and student of another UATI & 1.52 & 0.76 & 3.02 & & & \\
\hline \multicolumn{7}{|l|}{ Personal Development Scale (PDS) } \\
\hline \multicolumn{7}{|l|}{ Factor 1 (ref. Low) } \\
\hline Average & $2.42 * *$ & 1.27 & 4.60 & & & \\
\hline Factor 2 (ref. Low) & $3.63 * * *$ & 1.91 & 6.89 & $2.45 * * *$ & 1.47 & 4.08 \\
\hline \multicolumn{7}{|l|}{ Average } \\
\hline High & 1.37 & 0.72 & 2.61 & & & \\
\hline Factor 3 (ref. Low) & 1.30 & 0.74 & 2.27 & & & \\
\hline \multicolumn{7}{|l|}{ Average } \\
\hline High & 1.67 & 0.90 & 3.11 & & & \\
\hline Factor 4 (ref. Low) & 1.52 & 0.85 & 2.70 & & & \\
\hline \multicolumn{7}{|l|}{ Average } \\
\hline High & 1.66 & 0.89 & 3.09 & & & \\
\hline Factor 5 (ref. High) & 1.41 & 0.79 & 2.51 & & & \\
\hline \multicolumn{7}{|l|}{ Low } \\
\hline Average & 1.25 & 0.68 & 2.31 & & & \\
\hline High & 1.46 & 0.82 & 2.59 & & & \\
\hline \multicolumn{7}{|l|}{ PDS/Total (ref. Low) } \\
\hline Average & $3.47 * * *$ & 1.75 & 6.88 & & & \\
\hline High & $4.08 * * *$ & 2.11 & 7.90 & & & \\
\hline
\end{tabular}

Note. $95 \%$ CI O.R. $=95 \%$ Confidence Interval for the Risk Ratio. $* * p<0.01 * * * p<0.001$

psychologically resilient elderly people do not succumb to adversity; on the contrary, in their presence, they adapt positively, manage the events that threaten adaptation, or, after being affected by adversity, manage to recover their previous or baseline levels of SWB. Perhaps this mechanism can justify why subjective conditions are responsible for maintaining the psychological resilience of the elderly, even when biological resilience is compromised.
Another hypothesis for the older group to be more satisfied would be the coping mechanism known as the descending comparison. Comparing yourself with other people plays an important role in assessing and building reality and coping with negative events. On occasions that lead to a decline in well-being, people often compare themselves with others who they believe are worse in an effort to improve their well-being (Buunk et al., 2013). 
Table 3

Results of the Univariate and Multivariate Logistic Regression Analysis for High Scores on the Life Satisfaction Scale Referenced to Domains

\begin{tabular}{|c|c|c|c|c|c|c|}
\hline \multirow[b]{2}{*}{ Predictive Factors } & \multicolumn{3}{|c|}{ Univariate Analysis } & \multicolumn{3}{|c|}{ Multivariate Analysis } \\
\hline & Odds Ratio & CI 95\% & O.R. & Odds Ratio & CI 95\% & O.R. \\
\hline \multicolumn{7}{|l|}{ Gender (ref. female) } \\
\hline Female & 1.34 & 0.80 & 2.27 & & & \\
\hline \multicolumn{7}{|l|}{ Age } \\
\hline $65-69$ & 1.84 & 0.99 & 3.40 & & & \\
\hline 70 or more & 0.92 & 0.52 & 1.64 & & & \\
\hline \multicolumn{7}{|l|}{ Education (ref. Up to 4 years) } \\
\hline From 5 to 8 years & 1.07 & 0.49 & 2.32 & & & \\
\hline From 9 to 11 years & 1.18 & 0.52 & 2.66 & & & \\
\hline 12 years or more & 1.47 & 0.70 & 3.09 & & & \\
\hline \multicolumn{7}{|l|}{ Type of Participant (ref. New student) } \\
\hline Senior at EACH-USP $60+$ & 1.82 & 0.94 & 3.52 & & & \\
\hline New student and student from another UATI & 2.22 & 0.82 & 6.04 & & & \\
\hline Senior and student of another UATI & 1.67 & 0.82 & 3.37 & & & \\
\hline \multicolumn{7}{|l|}{ Personal Development Scale } \\
\hline \multicolumn{7}{|l|}{ Factor 1 (ref. Low) } \\
\hline Average & $2.75 * *$ & 1.41 & 5.35 & & & \\
\hline Factor 2 (ref. Low) & $6.63 * * *$ & 3.38 & 13.02 & $2.54 * *$ & 1.34 & 4.81 \\
\hline \multicolumn{7}{|l|}{ Average } \\
\hline High & $2.25^{*}$ & 1.17 & 4.35 & & & \\
\hline Factor 3 (ref. Low) & 2.35 & 1.33 & 4.15 & & & \\
\hline \multicolumn{7}{|l|}{ Average } \\
\hline High & 1.34 & 0.71 & 2.52 & & & \\
\hline Factor 4 (ref. Low) & $3.21 * * *$ & 1.78 & 5.82 & & & \\
\hline \multicolumn{7}{|l|}{ Average } \\
\hline High & 1.47 & 0.79 & 2.75 & & & \\
\hline Factor 5 (ref. High) & 1.51 & 0.85 & 2.69 & & & \\
\hline \multicolumn{7}{|l|}{ Low } \\
\hline Average & 1.08 & 0.59 & 1.99 & & & \\
\hline High & 1.31 & 0.74 & 2.32 & & & \\
\hline \multicolumn{7}{|l|}{ PDS/Total (ref. Low) } \\
\hline Average & $2.25 *$ & 1.14 & 4.43 & & & \\
\hline High & $6.02 * * *$ & 3.09 & 11.72 & $2.32 * *$ & 1.23 & 4.38 \\
\hline
\end{tabular}

Note. $95 \%$ CI O.R. $=95 \%$ Confidence Interval for the Risk Ratio. $* * p<0.01 * * * p<0.001$

Social comparison mechanisms are often better predictors of the well-being of the elderly than objective means such as health conditions. The elderly tend to make more descending than ascending comparisons, that is, they tend to compare themselves more with individuals in worse living and health conditions than his, as a protection strategy (Hampson et al., 2015; Kandler et al. , 2015; Gleason et al., 2014).
The total score of the Personal Development Scale and having high scores on Factor 1 of this scale were predictors of general satisfaction with life. Factor 1 of the Personal Development Scale assesses PWB in terms of self-fulfillment and personal growth and is concerned with intrapersonal psychological adjustment and the development of the self. According to Queroz (2008), self-fulfilled people 
Results of the Univariate and Multivariate Logistic Regression Analysis for High Total Score on the Mood State Scale

\begin{tabular}{|c|c|c|c|c|c|c|}
\hline & \multicolumn{3}{|c|}{ Univariate Analysis } & \multicolumn{3}{|c|}{ Multivariate Analysis } \\
\hline & Odds Ratio & CI 95\% & O.R. & Odds Ratio & CI 95\% & $O . R$. \\
\hline \multicolumn{7}{|l|}{ Predictive Factors } \\
\hline Gender (ref. female) & $1.76^{*}$ & 1.04 & 2.99 & $2.20 * *$ & 1.23 & 3.93 \\
\hline \multicolumn{7}{|l|}{ Female } \\
\hline Age & 1.55 & 0.84 & 2.86 & 1.29 & 0.67 & 2.48 \\
\hline $65-69$ & $2.30 * *$ & 1.29 & 4.10 & $2.57 * *$ & 1.40 & 4.74 \\
\hline \multicolumn{7}{|l|}{70 or more } \\
\hline Education (ref. Up to 4 years) & 1.95 & 0.89 & 4.26 & & & \\
\hline From 5 to 8 years & 1.88 & 0.82 & 4.27 & & & \\
\hline From 9 to 11 years & 1.26 & 0.60 & 2.67 & & & \\
\hline \multicolumn{7}{|l|}{12 years or more } \\
\hline Type of Participant (ref. New student) & 1.16 & 0.61 & 2.20 & 0.99 & 0.50 & 1.97 \\
\hline Senior at EACH-USP $60+$ & 0.85 & 0.32 & 2.27 & 0.93 & 0.33 & 2.65 \\
\hline $\begin{array}{l}\text { New student and student from another } \\
\text { UATI }\end{array}$ & 1.92 & 0.96 & 3.83 & 2.06 & 0.98 & 4.35 \\
\hline \multicolumn{7}{|l|}{ Senior and student of another UATI } \\
\hline \multicolumn{7}{|l|}{ Personal Development Scale } \\
\hline Factor 1 (ref. Low) & 1.73 & 0.94 & 3.21 & & & \\
\hline Average & $2.48 * *$ & 1.34 & 4.59 & & & \\
\hline \multicolumn{7}{|l|}{ Factor 2 (ref. Low) } \\
\hline Average & 1.17 & 0.61 & 2.21 & & & \\
\hline High & 1.30 & 0.75 & 2.27 & & & \\
\hline \multicolumn{7}{|l|}{ Factor 3 (ref. Low) } \\
\hline Average & 1.43 & 0.77 & 2.64 & & & \\
\hline High & $1.98^{*}$ & 1.11 & 3.52 & & & \\
\hline \multicolumn{7}{|l|}{ Factor 4 (ref. Low) } \\
\hline Average & 0.97 & 0.52 & 1.80 & & & \\
\hline High & 1.29 & 0.73 & 2.29 & & & \\
\hline \multicolumn{7}{|l|}{ Factor 5 (ref. High) } \\
\hline Low & 0.68 & 0.37 & 1.25 & & & \\
\hline Average & 0.76 & 0.43 & 1.35 & & & \\
\hline \multicolumn{7}{|l|}{ High } \\
\hline PDS/Total (ref. Low) & 1.88 & 0.99 & 3.55 & & & \\
\hline Average & $2.66^{* *}$ & 1.43 & 4.91 & $2.08 * *$ & 1.23 & 3.53 \\
\hline
\end{tabular}

Note. $95 \%$ CI O.R. $=95 \%$ Confidence Interval for the Risk Ratio. ${ }^{* *} p<0.01 * * * p<0.001$

are communicative, assertive, socially interactive and have a great perception of their capacity and value. These characteristics of pursuit of personal excellence can very possibly only be achieved by those who deal favorably with their emotions and are satisfied with life.

Men report a more positive emotional state, and older people, regardless of gender, have a high sense of SWB in all measures. Showing a positive sense of SWB at higher levels than that of younger people can demonstrate that older students have lower levels of aspiration, but it also demonstrates the ability to adjust personal goals to available skills and resources.

The factors of the Personal Development Scale concern the challenges and difficulties that the individual experiences 
Table 5

Results of the Univariate and Multivariate Logistic Regression Analysis for High Score on the Total Personal Development Scale

\begin{tabular}{|c|c|c|c|c|c|c|}
\hline \multirow[b]{2}{*}{ Predictive Factors } & \multicolumn{3}{|c|}{ Univariate Analysis } & \multicolumn{3}{|c|}{ Multivariate Analysis } \\
\hline & CI 95\% & O.R. & Odds Ratio & CI 95\% & O.R. & Odds Ratio \\
\hline \multicolumn{7}{|l|}{ Gender (ref. female) } \\
\hline Female & 1.24 & 0.73 & 2.12 & & & \\
\hline \multicolumn{7}{|l|}{ Age } \\
\hline $65-69$ & 1.21 & 0.65 & 2.25 & & & \\
\hline 70 or more & 0.86 & 0.48 & 1.52 & & & \\
\hline \multicolumn{7}{|l|}{ Education (ref. Up to 4 years) } \\
\hline From 5 to 8 years & 1.06 & 0.48 & 2.36 & 1.14 & 0.49 & 2.66 \\
\hline From 9 to 11 years & 1.29 & 0.56 & 2.96 & 1.41 & 0.58 & 3.46 \\
\hline 12 years or more & $2.21 *$ & 1.04 & 4.72 & $2.61 *$ & 1.14 & 5.97 \\
\hline \multicolumn{7}{|l|}{ Type of Participant (ref. New student) } \\
\hline Senior at EACH-USP $60+$ & 1.01 & 0.53 & 1.93 & & & \\
\hline New student and student from another UATI & 0.96 & 0.36 & 2.59 & & & \\
\hline Senior and student of another UATI & 0.83 & 0.41 & 1.67 & & & \\
\hline \multicolumn{7}{|l|}{ General Satisfaction with Life Scale (GSL) } \\
\hline \multicolumn{7}{|l|}{ GSL / Total (ref. Low) } \\
\hline Average & $3.06^{* * *}$ & 1.64 & 5.7 & & & \\
\hline High & 2.30 & 1.16 & 4.53 & & & \\
\hline \multicolumn{7}{|c|}{ Life Satisfaction Scale Referenced to Domains (LSD) } \\
\hline \multicolumn{7}{|l|}{ Health (ref. Low) } \\
\hline Average & 1.39 & 0.77 & 2.48 & & & \\
\hline High & $1.97 *$ & 1.06 & 3.67 & & & \\
\hline \multicolumn{7}{|l|}{ Physical Capacity (ref. Low) } \\
\hline Average & 1.69 & 0.95 & 3.01 & & & \\
\hline High & $3.03 * *$ & 1.55 & 5.94 & & & \\
\hline \multicolumn{7}{|l|}{ Mental Capacity (ref. Low) } \\
\hline Average & $2.03 *$ & 1.12 & 3.69 & & & \\
\hline High & $5.29 * * *$ & 2.63 & 10.65 & & & \\
\hline \multicolumn{7}{|l|}{ Social Involvement (ref. Low) } \\
\hline Average & $3.19 * * *$ & 1.68 & 6.06 & & & \\
\hline High & $6.10^{* * *}$ & 3.01 & 12.38 & $2.97 * *$ & 1.50 & 5.88 \\
\hline \multicolumn{7}{|l|}{ LSD / Total (ref. Low) } \\
\hline Average & $3.60 * * *$ & 1.84 & 7.06 & & & \\
\hline High & $7.43 * * *$ & 3.74 & 14.74 & $2.56^{* *}$ & 1.43 & 4.60 \\
\hline \multicolumn{7}{|l|}{ Mood State Scale (MS) } \\
\hline \multicolumn{7}{|l|}{ Positives (PMS) (ref. Low) } \\
\hline Average & $1.94 *$ & 1.08 & 3.47 & & & \\
\hline High & $4.07 * * *$ & 2.06 & 8.04 & & & \\
\hline \multicolumn{7}{|l|}{ Negatives (NMS) (ref. High) } \\
\hline Low & 1.52 & 0.83 & 2.79 & & & \\
\hline Average & 1.38 & 0.75 & 2.54 & & & \\
\hline \multicolumn{7}{|l|}{ MS / Total (PMS - NMS) (ref. Low) } \\
\hline Average & 1.65 & 0.88 & 3.09 & & & \\
\hline High & $2.50 * *$ & 1.36 & 4.58 & & & \\
\hline
\end{tabular}

Note. $95 \%$ CI O.R $=95 \%$ Confidence Interval for the Risk Ratio. ${ }^{*} p<0.05 * * p<0.01 * * * p<0.001$ 
throughout life and the evolutionary tasks that are part of his development. When trying to solve problems, the individual works positively, that is, he approaches psychological adjustment to the extent that he can develop characteristics and virtues that are part of the five factors of the scale. The more educated people may be able to apply the knowledge accumulated throughout life in a more effective way for personal improvement. Jongbloed (2018) corroborates this result by stating that higher educational levels affect PWB. Still, there are studies that show that life satisfaction (SWB) only gains importance in old age for individuals with a high level of education (Spuling et al., 2015).

Education is presented in literature as one of the strong determinants of SWB, with emphasis on young and middleaged people (Bauer et al., 2017). This data justifies the absence of evidence of significant results for this variable in the present study, since the sample is representative of elderly people. The fact that men have a higher level of education ( $M=10.88)$ did not reflect the general satisfaction score with life, corroborating findings in literature that schooling influences SWB in younger people, and not in the elderly (Nikolaev, 2018). Similar data were verified by Yang (2008). The author states that education is strongly related to happiness at all ages, except among elderly people. In the investigation of the role of sociodemographic characteristics in happiness, carried out in a sample of 467 people aged between 15 and 66 years, Rodrigues and Silva (2010) describe that schooling and education were not related to SWB.

It can be concluded that the opportunities for education offer important attributes for the individual to participate in activities for the acquisition of knowledge and make social connections that are linked to well-being, but are not associated with SWB, especially for this sample. It is also concluded that in this study there was no influence on the time of student participation in UATI in SWB and PWB when comparing samples of freshman and senior elderly. Although, research points out the benefits on the symptoms of depression for those who have been at UATIs for more than a semester, no studies were found that discuss the relationship between the time of participation in UATIs and well-being (Batistoni et al., 2011; Ordonez et al., 2011).

EACH-USP $60+$ and other programs offer features that strengthen existing functionality and, at the same time, compensate for others in the process of declining. This process is described by the selection, optimization and compensation (SOC) model, developed by Baltes and Baltes (1990). Not only are physical, cognitive and psychological skills optimized, but also established social relationships can be more significant.

It is important to note that this study has some limitations. The main one is that the sample is not representative of the elderly Brazilian population, since the average level of education is higher. In theory, it can be said that it is representative of the population attending educational programs for the elderly. It can also be considered a limitation the fact that the students already have characteristics of a successful and active aging, since they answered the call made by the programs. It is noted that the empirical work carried out so far has been of a cross-cutting nature. Future research should examine the action of time and the associations SWB and PWB in UATI students.

Among the characteristics that strengthen the study is that of being a pioneer in national literature. Both in the representative number of elderly people in a UATI, as well as in the investigated theme, there are no other studies that have used instruments of joint assessment of the two constructs - SWB and PWB. Validated instruments were used for the elderly Brazilian population, applied by a team of teachers and students trained for the procedures.

\section{REFERENCES}

Adamo, C.E., Esper, M.T., Bastos, G.C.F.C., Sousa, I.F., \& Almeida, R.J. (2017). Universidade aberta para a terceira idade: O impacto da educação continuada na qualidade de vida dos idosos. Revista Brasileira de Geriatria e Gerontologia, 20(4), 545-555. https://doi.org/10.1590/1981-22562017020.160192

Aknin, L. B., Barrington-Leigh, C. P., Dunn, E. W., Helliwell, J. F., Burns, J., Biswas-Diener, R., Kemeza, I., Nyende, P., Ashton-James, C. E., \& Norton, M. I. (2013).Prosocial spending and well-being: Crosscultural evidence for a psychological universal. Journal of Personality and Social Psychology, 104(4): 635-52.

Aparicio, J.E.V. (2014). Educación permanente: Los programas universitarios para mayores em España como respuesta a uma nueva realidade social. Revista de Educación Superior, 43(171):117-138.

Baltes, P. B. \& Baltes, M. M. (1990). Psychological perspectives on successful aging: The model of selective optimization with compensation. In P.B. Baltes \& M.M. Baltes (Eds.), Successful aging: Perspectives from the behavioral sciences (pp. 1-34). Cambridge University Press.
Bandura, A. (2006). Toward a psychology of human agency. Perspectives on psychological science, 1(2), 164-180. https:// doi.org/10.1111/j.1745-6916.2006.00011.x

Barber, S. J., Opitz, P. C., Martins, B., Sakaki, M., \& Mather, M. (2016). Thinking about a limited future enhances the positivity of younger and older adults' recall: Support for socioemotional selectivity theory. Memory \& cognition, 44(6), 869-882. https:// doi.org/10.3758/s13421-016-0612-0

Batistoni, S. S. T., Ordonez, T. N., Silva, T. B. L. D., Nascimento, P. P. P. D., Kissaki, P. T., \&Cachioni, M. (2011). Depressive symptoms in elderly participants of an open university for elderly. Dementia \&Neuropsychologia, 5(2), 85-92.

Batz-Barbarich, C., Tay, L., Kuykendall, L., \& Cheung, H. K. (2018). A meta-analysis of gender differences in subjective well-being: Estimating effect sizes and associations with gender inequality. Psychological Science, 29(9), 1491-1503. https:// doi.org/10.1177/0956797618774796

Bauer, J. M., Levin, V., Boudet, A. M. M., Nie, P., \& Sousa-Poza, A. (2017). Subjective well-being across the lifespan in Europe 
and Central Asia. Journal of Population Ageing, 10(2), 125158. https://doi.org/10.1007/s12062-016-9148-0

Buunk, B. P., Gibbons, F. X., \&Buunk, A. (2013). Health, coping, and well-being: Perspectives from Social Comparison Theory. Psychology Press.

Camargo, M. C., Lima-Silva, T. B., Ordonez, T. N., Batistoni, S. S. T., Yassuda, M. S., de Melo, R. C., Lopes, A., Domingues, M. A. R. d. C., \&Cachioni, M. (2018). Beliefs, perceptions, and concepts of old age among participants of a University of the Third Age. Psychology \& Neuroscience, 11(4), 417-425. https://doi.org/10.1037/pne0000117

Campbell, A., Converse, P. E., \& Rodgers, W. L. (1976). The quality of American life: Perceptions, evaluations, and satisfactions. Russell Sage Foundation.

Carmel, S., Raveis, V. H., O’Rourke, N., \&Tovel, H. (2017). Health, coping and subjective well-being: Results of a longitudinal study of elderly Israelis. Aging \& Mental Health, 21(6), 616623. https://doi.org/10.1080/13607863.2016.1141285

Carstensen, L. L., \&DeLiema, M. (2018). The positivity effect: a negativity bias in youth fades with age. Current Opinion in Behavioral Sciences, 19, 7-12. https://doi.org/10.1016/j. cobeha.2017.07.009

Charles, S., \& Carstensen, L. L. (2010). Social and emotional aging. Annual Review of Psychology, 61, 383-409. https://doi. org/10.1146/annurev.psych.093008.100448

Chopik, W. J., Newton, N. J., Ryan, L. H., Kashdan, T. B., \& Jarden, A. J. (2019). Gratitude across the life span: Age differences and links to subjective well-being. The Journal of Positive Psychology, 14(3), 292-302. https://doi.org/10.1080/174397 60.2017.1414296

Diener, E., \& Ryan, K. (2009). Subjective well-being: A general overview. South African Journal of Psychology, 39(4), 391406. https://doi.org/10.1177/008124630903900402

Fontes, A. P., \&Neri, A. L. (2015). Resiliência e velhice: Revisão de literatura. Ciência\&SaúdeColetiva, 20(5), 1475-1495. https:// doi.org/10.1590/1413-81232015205.00502014

Formosa, M. (2014). Four decades of Universities of Third Age : Past, present, future. Ageing Soc,34(1) :42-66. https://doi. org/10.1017/S0144686X12000797

Gildner, T. E., Liebert, M. A., Capistrant, B. D., D’Este, C., Snodgrass, J. J., \& Kowal, P. (2019). Perceived income adequacy and well-being among older adults in six low-and middle-income countries. The Journals of Gerontology: Series B, 74(3), 516-525.

Gleason, M.E.J., Weinstein, Y., Balsis, S., \&Oltmanns, T.F. (2014). The Enduring Impact of Maladaptive Personality Traits on Relationship Quality and Health in Later Life. Journal of Personality, 82(6), 493-501. https://doi.org/10.1111/ jopy. 12068

Gunder, E.S. (2014). Third age perspectives on lifelong learning: Third Age University. Procedia Soc Behav Sci, 116:1165-1169. https://doi.org/10.1016/j.sbspro.2014.01.363

Hair, J. F., Anderson, R. E., Tatham, R. L. \& Black, W. C. (2005). Análisemultivariada de dados. Artmed.

Hampson, S.E, Edmonds, G.W., Barckley, M., Goldberg, L.R., Dubanoski, J. P., \& Hillier, T. A. (2015). A Big Five approach to self-regulation: Personality traits and health trajectories in the Hawaii longitudinal study of personality and health. Psychology, Health \& Medicine, 21(2), 152-162.https://doi. org/10.1080/13548506.2015.1061676

Parte superior do formulário

Jivraj, S., Nazroo, J., Vanhoutte, B., \&Chandola, T. (2014). Aging and subjective well-being in later life. The Journals of Gerontology - Series B, Psychological Sciences and Social Sciences, 69(6), 930-941.https://doi.org/10.1093/geronb/ gbu006

Jongbloed, J. (2018). Higher education for happiness? Investigating the impact of education on the hedonic and eudaimonic well-being of Europeans. European Educational Research Journal, 17(5), 733-754. https://doi. org/10.1177/1474904118770818

Kandler, C., Kornadt, A. E., Hagemeyer, B., \&Neyer, F. J. (2015). Patterns and sources of personality development in old age. Journal of Personality and Social Psychology, 109(1), 175-191. https://doi.org/10.1037/pspp0000028

Karppinen, H., Pitkälä, K. H., Kautiainen, H., Tilvis, R. S., Valvanne, J., Yoder, K., \& Strandberg, T. E. (2017). Changes in disability, self-rated health, comorbidities and psychological well-being in community-dwelling 75-95-year-old cohorts over two decades in Helsinki. Scandinavian Journal of Primary Health Care, 35(3), 279-285. https://doi.org/10.1080/02813432.201 7.1358855

Kendig, H., Loh, V., O’Loughlin, K., Byles, J., \&Nazroo, J. Y. (2016). Pathways to well-being in later life: Socioeconomic and health determinants across the life course of australian baby boomers. Journal of Population Ageing, 9, 49-67. https://doi. org/10.1007/s12062-015-9132-0

Lawton, M. P. (1991). A multidimensional view of quality of life in frail elders. In J. E. Birren, J. E. Lubben, J.C. Rowe, \& D.E. Deutchman (Orgs). The concept and measurement of quality of life in the frail elderly (pp.3-27). Academic Press.

Mroczek, D. K., Weston, S. J., \&Willroth, E. C. (2020). A Lifespan perspective on the interconnections between personality, health, and optimal aging. In P. Hill \& M. Allemand (Eds.),Personality and Healthy Aging in Adulthood (p. 191-202). Springer, Cham.

Narushima, M., Liu, J., \&Diestelkamp, N. (2018). Lifelong learning in active ageing discourse: Its conserving effect on wellbeing, health and vulnerability. Ageing and Society, 38(4), 651-675. https://doi.org/10.1017/S0144686x16001136

Nikolaev, B. (2018). Does higher education increase hedonic and eudaimonic happiness? Journal of happiness Studies, 19(2), 483-504. http://link.springer.com/10.1007/s10902-016-9833-y

Ordonez, T. N., Batistoni, S. S. T., \&Cachioni, M. (2011). Síntomasdepresivosen adultos mayores participantes de una universidadabierta a laterceraedad. Revista Española de Geriatría y Gerontología, 46(5), 250-255.

Queroz, N. C. (2008). Bem-estar psicológico: Investigações acerca de recursos adaptativos em adultos e na meia-idade [Tese de doutorado não publicada]. Faculdade de Educação, Universidade Estadual de Campinas.

Rodrigues, A., \& Silva, J. A. d. (2010). O papel das características sociodemográficas na felicidade. Psico-USF, 15(1), 113-123. https://doi.org/10.1590/S1413-82712010000100012

Ryff, C. D. (1989). Happiness is everything, or is it? Explorations on the meaning of psychological well-being. Journal of Personality and Social Psychology, 57(6), 1069-1081. http:// psycnet.apa.org/buy/1990-12288-001

Ryff, C. D. (2018). Eudaimonic well-being: Highlights from 25 years of inquiry. In K. Shigemasu, S. Kuwano, T. Sato, \& T. Matsuzawa (Eds.), Diversity in harmony - Insights from psychology: Proceedings of the 31st International Congress of Psychology (pp. 375-395). John Wiley \& Sons Ltd. https:// doi.org/10.1002/9781119362081.ch20

Ryff, C. D., \& Keyes, C. L. M. (1995). The structure of psychological well-being revisited. Journal of Personality and Social Psychology, 69(4), 719-727. https://doi.org/10.1037/00223514.69.4.719

Santos, A. (2003). Controle percebido, senso de auto-eficácia e satisfação com a vida: Um estudo comparativo entre homens e mulheres pertencentes a três grupos de idade. [Tese de Doutorado não-publicada]. Universidade Estadual de Campinas.

Sapranaviciute -Zabazlajeva, L., Luksiene, D., Virviciute, D., Kranciukaite-Butylkiniene, D., Bobak, M., \&Tamosiunas, A. (2018). Changes in psychological well-being among older Lithuanian city dwellers: Results from a cohort 
study. International Journal of Clinical and Health Psychology, 18(3), 218-226. https://doi.org/10.2105/ AJPH.2010.193391

Siqueira, M., Martins, M., \& Moura, O. (1999). Construção e validação fatorial da EAPN: Escala de Ânimo Positivo e Negativo. Revista da Sociedade de Psicologia do Triângulo Mineiro, 2(3), 34-40.

Springer, K. W., Pudrovska, T., \& Hauser, R. M. (2011). Does psychological well-being change with age? Longitudinal tests of age variations and further exploration of the multidimensionality of Ryff's model of psychological wellbeing. Social Science Research, 40(1), 392-398. https://doi. org/10.1016/j.ssresearch.2010.05.008

Spuling, S.M., Huxhold, O., \& Wurm, S. (2015). Predictors of self-rated health: Does education play a role above and beyond age? The Journals of Gerontology - series B: Psychological
Sciences and Social Sciences, 72(3), 415-424. https://doi. org/10.1093/geronb/gbv057

Steptoe, A., Deaton, A., \& Stone, A. A. (2015). Subjective wellbeing, health, and ageing. The Lancet, 385(9968), 640-648. https://doi.org/10.1016/S0140-6736(13)61489-0

Suh, E. M., \& Choi, S. (2018). Predictors of subjective wellbeing across cultures. In E. Diener, S. Oishi, \& L. Tay (Eds.), Handbook of well-being. DEF Publishers.

Yang, Y. (2008). Social inequalities in happiness in the United States, 1972 to 2004: An age-period-cohort analysis. American Sociological Review, 73(2), 204-226. https://doi. org/10.1177/000312240807300202

Zielińska-Więczkowska, H. (2017) Correlations between satisfaction with life and selected personal resources among students of Universities of the Third Age. Clinical Interventions in Aging, 12, 1391-1399. https://doi.org/10.2147/CIA.S141576 